\title{
Contextual Teaching Learning in the Development of a Student's Environmental Care Attitude During the Covid-19 Pandemic
}

\author{
Paloma Humana ${ }^{1, *}$, Rahmat Rahmat ${ }^{2}$ \\ 1,2, Universitas Pendidikan Indonesia, Bandung, Indonesia \\ *Corresponding Authors.Email:myself_opals@upi.edu
}

\begin{abstract}
The world of education is one of the vital assets for the progress of a nation, which is currently being hampered by the Covid-19 pandemic, so that teaching and learning activities in schools have changed drastically into online learning from their respective homes. This is a challenge in itself for students and teachers who have to guide and direct learning, especially civic lesson, one of which is through a contextual approach so that students are able to develop and have a caring attitude towards the environment. The purpose of this research is to describe the development of environmental care for students during the Covid-19 pandemic through contextual-based civic education learning. This research was conducted through a qualitative approach with literature study methods, data analysis focused on: data reduction, display verification data or drawing conclusions. The results showed: 1) the contextual approach made it easier for students to find out for themselves the meaning contained and the relationship between the knowledge obtained from the civic education and the environmental conditions during the pandemic even though the learning was carried out online, 2) the contextual approach in civic education learning was able to make students become individual, social beings and as good citizens. The conclusion of the study is that students are able to understand knowledge in civic education learning through a contextual approach which is one of the alternative learning, making it easier for students to relate teaching material to its direct application in everyday life in the current pandemic conditions.
\end{abstract}

Keywords: Civic Education, Contextual Approach, Environmental Care.

\section{INTRODUCTION}

Currently the whole world is being "attacked" by the condition of the Covid-19 which is spreading rapidly so that it becomes a pandemic. The arrival of has become a global problem experienced by all residents in the world, including in Indonesia. The Covid-19 was detected for the first time spreading in Wuhan, China and then spread rapidly to countries around the Asian continent and other continents. Slowly but surely the Covid-19 is not only deadly to the human body, but "paralyzes" all areas of human life, one of which is education. This can be seen from teaching and learning activities which are usually carried out in schools, which have drastically changed to online learning at their homes.

The government wants to minimize the spread of Covid-19 so that it does not increase sharply, then Circular Letter No. 15 of 2020 concerning Guidelines for the Implementation of Learning From Home (LFH) in an Emergency Period of Covid-19 Spread by the Ministry of Education and Culture. Nadiem A. Makarim (Minister of Education and Culture) emphasized that teaching and learning activities must provide meaningful learning experiences for students, without being burdened with demands to complete all curriculum achievements for grade promotion and graduation. In addition, the Minister of Education and Culture also provides advice to all regions in Indonesia that have implemented LFH to ensure teachers also teach from home for health safety.

The Covid-19 pandemic is forcing everyone to live a clean life, because it has an impact on changing human behavior norms in interacting with other people and the environment. The link between this pandemic environment and the LFH system provides good news as well as sad news. On the one hand, the government has quarantined several areas or better known as Large-Scale Social Restrictions where all community activities from work to school are carried out at home, each of which has a good effect on environmental conditions, namely the level of air pollution has decreased drastically.

This is a challenge for both students and teachers. Students must be guided and directed to have a caring attitude towards the environment during the Covid-19 
pandemic through various learning approaches in every subject, especially civics. Likewise, teachers must be able to focus LFH on life skills education, including regarding the Covid-19 pandemic.

One of the various learnings to create an attitude of caring for the environment is through a contextual approach. Indeed, an approach in learning is implemented to make it easier to apply by all students and teachers. Such as the learning method with a contextual approach which is a learning activity that is carried out holistically in education with the aim of giving students more motivation to understand the meaning of the subject matter being taught so that they are able to relate their knowledge and skills flexibly. in their daily lives (personally, socially and culturally) which eventually they will have the ability to solve one problem to another [1].

This study aims to describe the development of students' environmental care attitudes during the Covid19 pandemic through contextual-based civic education learning.

\section{THEORETICAL REVIEW}

\subsection{Civics Education}

Citizenship Education is one of the lessons that has a very important main part in the implementation of formal learning in schools. We can see this from the status of Civics subjects which are mandatory in the education curriculum. The existence of this mandatory status can be seen from the real realization that at all levels of education there must be Civics, such as starting from elementary school, junior high school, high school, and college.

Citizenship Education is part of social science education which requires strategies for learning so as to provide convenience to students in understanding and deepening what is taught. The material taught is not only rote that must be remembered. It is said that civic education can be interpreted as one way to prepare the younger generation as the nation's successors who have the skills to become a citizen who has the skills, knowledge and values to actively participate in society [2].

In addition, it was also explained that the learning carried out by civic education subjects was oriented to a concept that became the orientation of "contextualized multiple intelligence" education, which means that learning must be carried out in various ways and handling with the view that learning must be made more creative, active-participatory. , explore and develop students' abilities according to their potential or original intelligence, meaningful and fun [3]. Therefore, it is necessary to apply contextual teaching and learning in civic education learning, especially in the conditions of the Covid-19 pandemic.

\subsection{Contextual Teaching Learning}

CTL is a concept in which a teacher makes a connection between the theoretical material being taught with the reality in the field and provides encouragement to students to be able to make connections between the knowledge they have acquired and their implementation in their lives both as individuals and members of society [4]. This is in accordance that the application of contextual learning will greatly help teachers to relate subject matter with real-world situations and motivate students to form relationships between knowledge and apply them in daily life as family and community members [5].

Then, another opinion says that the CTL approach is an approach involving active students in the learning process to discover the concepts learned by linking the material with the knowledge they possess and the students experience in daily life [6]. Furthermore, Johnson says that learning with CTL approach, students are invited actively to be able to connect the content of the material to the context of everyday life of the students, so that it can bring understanding and intact meaning [7]. In addition, contextual learning can be described, as follows:

\subsection{Caring for the Environment}

The attitude of caring for the environment is very important as a hereditary habituation so that they have a wise attitude in environmental management. As it is known that with education, human attitudes can be changed and educated. The attitude of caring for the environment can be accustomed from the smallest things, for example throwing garbage in its place, separating organic waste from non-organic waste, planting trees, using natural resources (SDA) in moderation and maintaining environmental cleanliness [8].

Concern for the environment is a form of willingness that arises in a person (internal drive) to take concrete actions to protect, care for, maintain, and improve the quality of an environment. The attitude of caring for the environment if it is always carried out continuously and continuously is automatically able to shape a person's character so that he is more concerned about the surrounding environment.

It was further said that "Caring for the environment is a behavior that always tries to prevent damage to the surrounding natural environment and seeks to repair the damage that has occurred and always wants to provide assistance to everyone in need"[9].

From a qualitative perspective, the decline in the national education system occurs because learning in schools is still focused on the information-transmitting paradigm that involves low-level cognitive skills, namely memorization. The method that is often used in this kind of learning is expository such as lectures, reading assignments, recitations, questions and answers, and written exercises. The main sources are teacher presentations, textbooks, films, videos, or other information provision. Thus, learning is centered on the 
teacher because the teacher is the source of all this information [10].

The learning paradigm of civic education which is considered to be far from what is expected due to the weak approach to learning carried out by teachers is one of the factors that hinders the realization of the civisc education mission to create democratic and participatory citizens. This happens because there are still some teachers who have not implemented contextual learning, even though it is undeniable that teachers are at the forefront of being able to realize the mission of citizenship education with a new paradigm that lies in the hard work of teachers to always be innovative and creative in developing civics approaches [11].

In addition, the learning of Citizenship Education is less meaningful for students due to the still dominant application of conventional learning methods such as ground covering technique, narrative technique, and indoctrination in learning [12]. In school conditions that are forced to be carried out online because the impact of Covid-19 causes various variants of obstacles in the implementation of learning, such as:

1. Limited mastery of information technology by teachers and students

2. Inadequate facilities and infrastructure

3. Limited internet access

4. Unprepared budget provision [13]

Based on the result of a review of 10 literatures that researchers analyzed from various sources of information, such as scientific research journals, the results are shown in the following table.

Table 1. Summary of Literature on Contextual Learning

\begin{tabular}{|c|c|c|c|c|c|}
\hline No. & Autor/Jurnal & $\begin{array}{r}\text { Type of } \\
\text { Research } \\
\end{array}$ & $\begin{array}{l}\text { Instrument/Method of } \\
\text { data collection }\end{array}$ & Sample/Object & Result \\
\hline 1 & $\begin{array}{c}\text { I Dewa Gede } \\
\text { Paramaweda, I Putu } \\
\text { Sriarta, dan I Wayan } \\
\text { Kertih (2018) }\end{array}$ & $\begin{array}{c}\text { Quasi } \\
\text { Esperimental }\end{array}$ & $\begin{array}{c}\text { test and } \\
\text { questionnaires }\end{array}$ & $\begin{array}{l}190 \text { students of VII } \\
\text { grade }\end{array}$ & $\begin{array}{l}\text { CTL model is better than the conventional } \\
\text { learning model in improving social studies } \\
\text { learning outcomes and student environmental } \\
\text { awareness. }\end{array}$ \\
\hline 2 & $\begin{array}{c}\text { Rini Ayu Sih } \\
\text { Nugraheni (2015) }\end{array}$ & $\begin{array}{c}\text { Quasi } \\
\text { Esperimental }\end{array}$ & $\begin{array}{c}\text { questionnaire and } \\
\text { observations }\end{array}$ & $\begin{array}{l}42 \text { students in class } \\
\text { IVA and IVB }\end{array}$ & $\begin{array}{l}\text { Learning using CTL better strategy in developing } \\
\text { a caring attitude to the environment than a } \\
\text { lecture. The difference can looks at the } \\
\text { indicators: 1) clean garbage that clog waterways } \\
2 \text { ) do not burn trash around the housing. }\end{array}$ \\
\hline 3 & $\begin{array}{l}\text { Chafid Rohman } \\
\text { (2015) }\end{array}$ & $\begin{array}{c}\text { Quasi } \\
\text { Esperimental }\end{array}$ & $\begin{array}{l}\text { Test, observation, and } \\
\text { questionnaire }\end{array}$ & Students & $\begin{array}{l}\text { The results showed the influence of students' } \\
\text { understanding of the concept of the character } \\
\text { caring environment for students while the } \\
\text { remaining } 19.24 \% \text { influenced by other factors. }\end{array}$ \\
\hline 4 & $\begin{array}{l}\text { Heri Hidayat, Alfan } \\
\text { Siti Qurrotul Aini, } \\
\text { Heny Mulyani, Arlin } \\
\text { Sircahyati, Desi } \\
\text { Nuraisyah (2020) }\end{array}$ & $\begin{array}{l}\text { Descriptive } \\
\text { Qualitative }\end{array}$ & $\begin{array}{l}\text { Observation and } \\
\text { interviews }\end{array}$ & Teacher & $\begin{array}{l}\text { CTL method helps teachers links material which } \\
\text { is taught with students' real-world situations and } \\
\text { also attract the attention of the students because } \\
\text { they feel directly in an environment that is } \\
\text { familiar with their lives. }\end{array}$ \\
\hline 5 & $\begin{array}{l}\text { Kokom Komalasari } \\
\text { (2012) Journal for } \\
\text { Educational Studies. } \\
\text { Vol } 4 \text { (2). }\end{array}$ & $\begin{array}{l}\text { Quantitative } \\
\text { Approach }\end{array}$ & Survei & 1,004 students & $\begin{array}{l}\text { There was significant effect of CTL on students' } \\
\text { civic skills, which was shown with correlation by } \\
0.48 \text { and contribution by } 23 \% \text {. therefore, teachers } \\
\text { should apply contextual learning }\end{array}$ \\
\hline 6 & Surdin (2018) & $\begin{array}{l}\text { Classroom } \\
\text { Action } \\
\text { Research }\end{array}$ & $\begin{array}{l}\text { procedure Classroom } \\
\text { Action Research }\end{array}$ & students of class VII-C & $\begin{array}{l}\text { The result of this research is there is a positive } \\
\text { effect of CTL models to outcome learning social } \\
\text { science of the material of earth forms in class vii } \\
\text { students of the junior high school }\end{array}$ \\
\hline 7 & $\begin{array}{l}\text { Siti Arifatul Khasanah } \\
\text { (2019) }\end{array}$ & $\begin{array}{l}\text { descriptive } \\
\text { qualitative }\end{array}$ & $\begin{array}{l}\text { observation, } \\
\text { interviews, and } \\
\text { documentation. }\end{array}$ & $\begin{array}{l}\text { headmaster, teacher, } \\
\text { and students. }\end{array}$ & $\begin{array}{l}\text { From the results, it can be said that there is no } \\
\text { significant effect of the CTL model on student } \\
\text { learning outcomes, while the attitude of students } \\
\text { throwing garbage anywhere has a significant } \\
\text { effect. }\end{array}$ \\
\hline 8 & Tri Darmawati (2016) & $\begin{array}{l}\text { Qualitative } \\
\text { Approach. }\end{array}$ & $\begin{array}{c}\text { observation, } \\
\text { interviews and } \\
\text { documentation. }\end{array}$ & $\begin{array}{l}\text { Civics teachers, } \\
\text { students and principals }\end{array}$ & $\begin{array}{l}\text { student can create their learning classroom } \\
\text { themselves and being more creative. }\end{array}$ \\
\hline 9 & $\begin{array}{l}\text { Shinta Pertiwi and } \\
\text { Samsuri (2016) } \\
\end{array}$ & $\begin{array}{c}\text { Quasi } \\
\text { Esperimental } \\
\end{array}$ & $\begin{array}{l}\text { test, questionnaire, } \\
\text { and observation }\end{array}$ & Students grade VII & $\begin{array}{l}\text { Students will also be more motivated in } \\
\text { participating in learning civics education }\end{array}$ \\
\hline 10 & $\begin{array}{l}\text { Hermuning Puspita } \\
\quad \text { Sari (2013) }\end{array}$ & $\begin{array}{l}\text { Classroom } \\
\text { Action } \\
\text { Research }\end{array}$ & $\begin{array}{l}\text { test and non-test, } \\
\text { observation, } \\
\text { interview, } \\
\text { questionnaire } \\
\end{array}$ & Teacher and students & $\begin{array}{l}\text { Game method based CTL approach can improve } \\
\text { the quality of civics learning }\end{array}$ \\
\hline
\end{tabular}

Contextual learning in civics education subjects must be able to improve the skills of students physically and mentally considering the Covid-19 pandemic condition can affect their psyche. Sometimes a handful of people think "learning Civics at school is already difficult to understand in a concrete application, let alone learning online". To solve the problem of the meaninglessness of Civic Education learning, materials should not only contain mere memorization but are combined with actual life in society. 
This is in line with the opinion that "Citizenship Education will be more meaningful if functional knowledge and social problems enrich the basic concepts of Citizenship Education, and develop creative dialogue in learning", so that civic education learning is expected to develop all students' potential. [14]. Another opinion is that the application of contextual learning is an urgent need in solving Civics problems so far, so that it is considered as an alternative in solving problems in civics learning [15].

Based on several research articles published above, it illustrates that the contextual learning model has various advantages that can be one of the ways for teachers to carry out Current Distance Learning (CDL) during the pandemic outbreak so that each student has attitudes and behaviors that care about the environment, especially in learning civic education. This is also in accordance with the results of research conducted by Edi Suhartono (2015) on the Advantages of Contextual Approaches in Supporting Contextualized Multiple Intelligence Civics Learning, concluding that contextual learning is very suitable to be applied in civic education which has a competency goal to educate and prepare students to become citizens. a country that is good in society, nation and state, which is able to get connectedness between teaching materials and the context of everyday life.

\section{CONCLUSION}

Based on the results of research and discussion, it can be concluded that:

1. In Current Distance Learning (CDL) conditions, teachers must be able to become facilitators with broad insight to innovate in learning activities so that they are able to form students who have an attitude of caring for the environment.

2. The selection of a contextual learning approach or model can be an alternative solution for online learning methods that are adapted to government recommendations in the formation of student character, cognitive value recognition, affective appreciation of values and real value practice.

3. Teachers must be able to design interesting Current Distance Learning (CDL) assignments, arouse students' curiosity and demand active learning, such as formulating questions, finding and collecting various sources of information, processing data obtained, reconstructing data, and presenting the results. So that the Current Distance Learning (CDL) activities can foster character values in students.

Finally, educators must be able to innovate to make online learning as creative as possible so that character values can still be implemented.

\section{REFERENCES}

[1] Abdul Majid. Strategi Pembelajaran. Remaja Rosdakarya:Bandung. 2013

[2] Samsuri. Bahan kajian Kuliah Umum di Program Studi Pendidikan Pancasila dan Kewarganegaraan (PPKN) FKIP Universitas Ahmad Dahlan, Yogjakarta, 9 Mei 2011. Makalah Disajikan dalam diskusi tentang Best Practice Pembelajaran Pkn, dalam kajian mandiri kewarganegaraan di Program Studi PIPS Sekolah Pasca Sarjana Universitas Pendidikan Indonesia, Bandung, Semester Genap 2008 / 2009.

[3] Kokom Komalasari. 2008, p 47. Pengaruh Pembelajaran Kontekstual dalam Pendidikan Kewarganegaraan terhadap Kompetensi Kewarganegaraan Siswa SMP. Disertasi Doktor pada Sekolah Pasca Sarjana Universitas Pendidikan Indonesia. Tidak Diterbitkan

[4] Agus Suprijono. Cooperative Learning: Teori dan Aplikasi PAIKEM. Yogyakarta: Pustaka Belajar Suprijono. 2011

Johnson, Elaine B. Contextual Teaching and Learning: Menjadikan Kegiatan Belajar Mengajar Mengasyikkan dan Bermakna. Bandung: Kaifa. 2011

[5] Yetty Ellyana.. Pendekatan Kontekstual dalam Pembelajaran IPA. 2009(http://pendekatankontekstual.blogspot.com/2009/08/pendekatan kontektual dalam.html, diunduh tanggal 26 Juni 2021).

[6] Selvianiresa D. \& S. Prabawanto. International Conference on Mathematics and Science Education (ICMScE), IOP Conf. Series: Journal of Physics. 2017. Doi:10.1088/17426596/895/1/012171.

[7] Elaine B. Johnson. Contextual Teaching and Learning: What It Is and Why It's Here to Stay (California : Corwin Press, Inc). 2002, p 12.

[8] Syukri Hamzah. 2013. Pendidikan Lingkungan. Bandung: PT. Refika Aditama. 2013

[9] Zainal Aqib and Sujak. 2011. Panduan dan Aplikasi Pendidikan Karakter. Jakarta: Gaung Persada Press. 2011

[10] T. Raka Joni. Pembelajaran yang Mendidik: Artikulasi Konseptual, Terapan Kontekstual, dan Verifikasi Empirik. Malang: PPs Universitas Negeri Malang. 2005

[11] Samsuri, 2011. Bahan kajian Kuliah Umum di Program Studi Pendidikan Pancasila dan Kewarganegaraan (PPKN) FKIP Universitas Ahmad Dahlan, Yogjakarta, 9 Mei 2011. Makalah Disajikan dalam diskusi tentangbest practice pembelajaran Pkn, dalam kajian mandiri kewarganegaraan di Program Studi PIPS Sekolah 
Pasca Sarjana Universitas Pendidikan Indonesia, Bandung, Semester Genap 2008 / 2009.

[12] Nu'man Soemantri. Menggagas Pembaharuan Pendidikan IPS. Bandung: Remadja Rosdakarya. 2001

[13] R.H.S Aji. Dampak Covid-19 pada Pendidikan di Indonesia: Sekolah, Keterampilan, dan Proses Pembelajaran. Jurnal Sosial \& Budaya Syar-i FSH UIN Syarif Hidayatullah Jakarta. Vol. 7 No.5, 2020. DOI: $10.15408 /$ sjsbs.v7i5.15314
[14] Nu'man Soemantri. 2001. Menggagas Pembaharuan Pendidikan IPS. Bandung: Remadja Rosdakarya

[15] Kokom Komalasari. Efek dari Pembelajaran Kontekstual dalam Pendidikan Kewarganegaraan pada Kompetensii Kewargannnegaraan Siswa. Journal of Social Sciences. Vol 5 No. 4, 2009, pp. 261-270. Bandung: UP 